\title{
We Were There
}

\section{Rethinking Truth with Midiativistas in Rio de Janeiro}

\author{
Raffaella Fryer-Moreira
}

\begin{abstract}
The popular uprising in Brazil between 2013 and 2014 led to the emergence of midiativistas, media activists who produced audiovisual testimony from the front lines of protests. Their reports were grounded in their act of 'being there' and bearing witness, and the affective encounters that their position made possible. Their first-hand accounts were situated, partial, and deemed more convincing because they rejected the mainstream media's claims to 'objective truth' - as a view from everywhere that is simultaneously a view from nowhere (and no-one) - in favour of situated truth, witnessed directly, unsettling traditional divisions between representation and reality, and questioning the conditions (and relations) through which knowledge is produced. This ethnographic engagement with the knowledge practices of others, and the role of witnessing within them, reflects on anthropological knowledge practices more broadly, and how they may be conceived otherwise in light of empirical variants from our fields.
\end{abstract}

Keywords: knowledge, media activism, recursive anthropology, social movements, truth

\section{Introduction: we were there}

Protestors wearing black $t$-shirts and scarves across their faces hold up cardboard shields, shouting, 'There won't be a World Cup! There won't be a World Cup!' ... Cut to image of a tight line of riot police, shields raised. Sound of sirens. Cut to a woman grimacing and putting her hands over her face to protect it from pepper-spray ... Cut to a protestor shouting indignantly, 'What is this? Where are my rights? I want to protest! What country is this, where you can't protest? We were walking, and the police threw teargas at us as if we were anything but citizens. Not in Brazil'. Cut to images of riot police in all their body armour. 'We don't have the right to free protest.' Cut back to protestor shouting, 'Our government is inhuma-' - the boom of a stun grenade drowns 


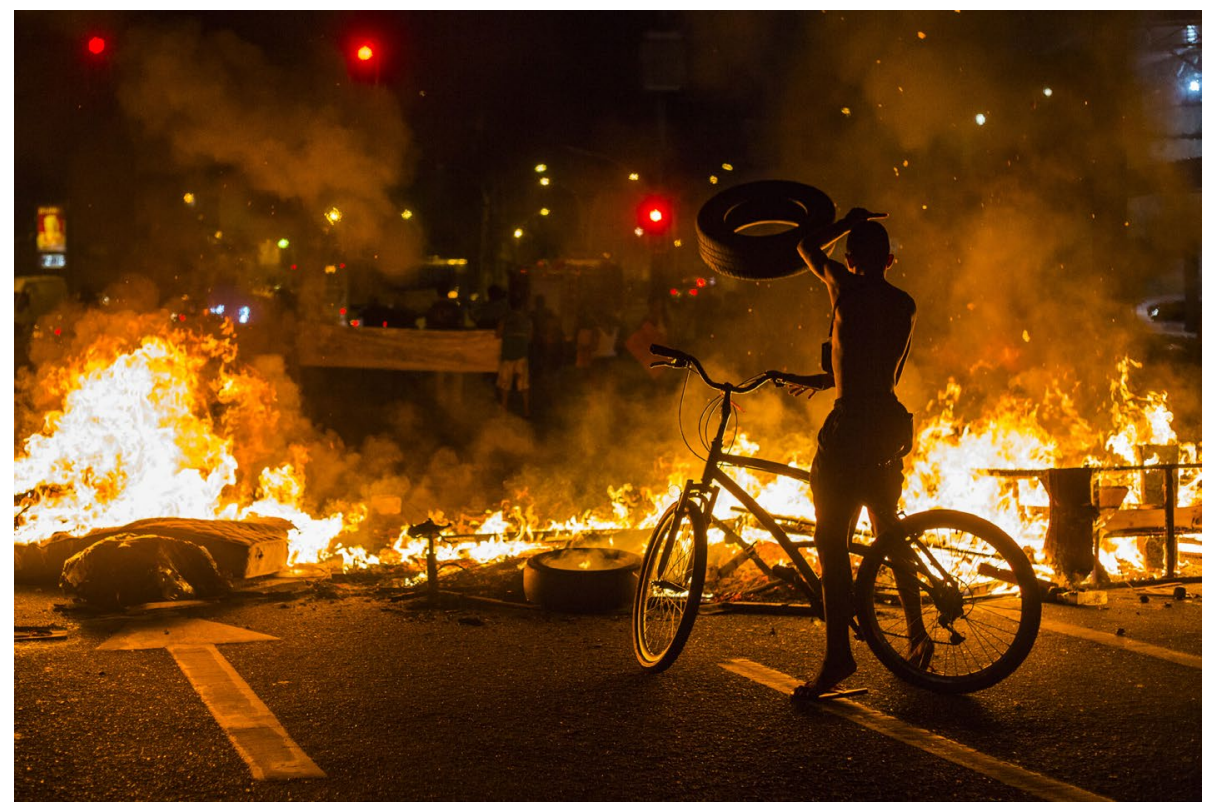

Figure 1: A favela community are forcibly evicted from their homes near the Maracanã Stadium in the run up to the FIFA World Cup. Photograph by Paula Kossatz.

out his sentence and makes him jump. Cut to image of policeman firing stun grenade gun, then camera jolts as a second boom echoes through the streets. Cut to wide image of streets, where a policeman in the distance aims his stun-grenade gun and shoots it, sending a stream of orange sparks hurtling through the street. A car alarm goes off. Cut to wide shot of street and another boom of a stun grenade resounds, the camera focusing on the smoke now filling the street, catching the glint of the red traffic lights.

-Transcribed extract of midiativista video, 15 June 2014, Rio de Janeiro, Brazil: 'Protest against the FIFA World Cup: Argentina vs Bosnia match at the Maracanã Stadium. Produced by Coletivo Mariachi and Mídia Independente Coletiva

The extract above is a transcript of a video that was made in June 2014 outside the Maracanã football stadium in Rio de Janeiro, documenting one of the hundreds of protests that took place during the largest popular mobilization in Brazilian history (Pomar 2013: 15). The video was made by midiativistas - collectives of media activists who emerged at the time to 'show the truth of what was happening on the streets', as my collaborator Pablo ${ }^{1}$ often put it. Their video reports were seen to be truthful and authoritative because they were made by insiders who 'were there' - whose physical proximity to the site of action and relational position within the protest movement enabled them to produce first-hand audiovisual testimony that was transparent about its partial and situated claims to truth. The video was produced through the collaborative effort of six midiativistas, whose situated insider positions in the protest space permitted the perspectives of six cameras to coalesce 
into one video report, offering a window into what the streets looked like from where they stood. As I was one of the six midiativistas who filmed and edited the video, it stands as an index of my presence as ethnographer, and the ethnographic choices I made which positioned me on the front line of the protest that day, being there and doing with with my collaborators. The video extract is consequently an artefact of both midiativista knowledge and anthropological knowledge, and invites us to reflect on one as a 'variant' (Maniglier 2009) of the other.

This article is concerned with the production of knowledge and truth. I am interested both in the production of knowledge of protest sites, such as the one described in the extract above, and in the production of anthropological knowledge, such as the article that follows, and I examine the role of witnessing in the production of both. I present an ethnographic account of the practices and processes, technologies and networks through which midiativista knowledge was produced, and examine the theories of truth in which this knowledge was grounded. I explore the role of 'being there' as a source of authority in both midiativismo and anthropology (Borneman and Hammoudi 2009), and unravel the webs of relatedness or 'co-presence' (Chua 2015) through which encounters with people and places - and knowledge of them - are made possible. As I will show, midiativistas conceive of relational entanglements within socio-material webs as the very condition of possibility of knowledge, and problematize claims to truth grounded in detached observation, rejecting the possibility of 'objective' truth. Midiativistas showed me that all observation is a form of action, and the scope of our actions shape the scope of what we can know. In my own search for an epistemological and ethical basis for the production of anthropological knowledge, I am indebted to my midiativista collaborators, who offered me new ways of making sense of the situated and partial positions from which we speak.

This article then has three aims: first, to provide an ethnographic account of the material practices and conceptual toolkits through which midiativistas witnessed and produced knowledge of their protest spaces; second, to draw on these ethnographic encounters to contribute towards current debates in the anthropological literature on witnessing (Fassin 2008, 2011; Givoni 2011, 2013; Grindal 1983; Marcus 2005, 2010; Reed-Danahay 2017; Scheper-Hughes 1992, 1995) where discussions surrounding the relative importance of participation (Grindal 1983; Scheper-Hughes 1992, 1995), in contrast to detached observation (Marcus 2005, 2010), may benefit from the insights drawn from a specific ethnographic case study of witnessing in action; finally, through an exercise of comparison between the role of witnessing in the knowledge practices of midiativismo and anthropology, this article explores how the concepts and practices through which anthropological knowledge is produced can themselves be rethought, and through engaging with the methods and ideas of the midiativistas with whom I worked, anthropological theory and methods can be informed ethnographically. 


\section{You don't represent me!}

'You don't represent me!' read a large banner being carried through the streets of Rio de Janeiro in one of the hundreds of protests that defined the political landscape in 2013-14. More than twelve million people took to the streets in Brazil in the month of June 2013 alone (Pomar 2013: 15), expressing their discontent with political representatives and their disillusionment with the mechanisms of political representation which denied them participation in the organization of social life. Within the diversity of critiques expressed by protestors - which addressed issues ranging from transport, education, healthcare and pensions, to corruption and state violence - their demands all reiterated a common call for greater participation in the way things were run. Popular assemblies organized throughout the city invited people to sit together in public spaces and discuss their individual concerns, seeking to preserve the heterogeneity through which they were composed as a source of strength, while working together to develop proposals for direct action and collective responses (Lobato 2016). This widespread rejection of the vertical structures of social and political representation led to the emergence of grassroots organizations, which endeavoured to find solutions to the issues that concerned them and which they felt their political representatives were either unable or unwilling to address.

In that moment people said, what will we do with this political moment, what will I do? Some threw stones and broke windows, others picked up cameras ... I think this moment is inevitable, the rupture with the representativity of the mediums of communication, which is also a rupture with traditional politics, this crisis of representativity will lead to this, to people wanting to represent themselves, and organize themselves autonomously. (Interview with Rubens, Mídia Independente Coletiva)

This critical interrogation of representation was quickly directed towards Brazil's media institutions, most notably the news network Rede Globo, whose early reports cast protestors as 'vandals' and dismissed police violence as a proportionate and appropriate state response. 'I'm not a vandal', said one collaborator indignantly, 'I'm not a trouble-maker, that's not what happened at all'. The stark discrepancy between media narratives and people's immediate experience of the protest space led many - some for the first time - to question the conditions and relations through which media reports were produced, and the political interests they served. Collaborators emphasized Rede Globo's historical roots in Brazil's military dictatorship from the 1960 s to the 1980s, and pointed to its role in unifying public opinion and silencing dissent. Many midiativistas maintain that its role in monopolizing established truth narratives and furthering particular political agendas was still a real concern, and the emergence of the midiativista movement (Fryer-Moreira 2016) can be understood in direct response to this critique of media representation, calling for greater participation in the mechanisms of communication. 


\section{A crisis in anthropological knowledge}

This critique of knowledge and political action drew attention to the material and relational conditions through which institutions chose to act and claimed to know. It occurred to me that my own endeavour to produce anthropological knowledge of the protest movement could be subjected to the same critique, and I questioned the conditions and relations through which I proposed to continue. Was it possible to produce an ethnographic account that was not an external and vertical representation of this movement, which so adamantly rejected representation? I was deeply affected by a sense of ethical and epistemological crisis, and questioned the possibility of conducting anthropological research at all. I needed to find a concept of knowledge that could withstand the important questions my collaborators asked of it, and establish whether knowledge was still a feasible or ethical goal.

The theoretical trajectory through which anthropology has questioned the conditions of possibility of its own claims to knowledge (e.g. Asad 1986; Clifford and Marcus 1986; Marcus and Fischer 1986) presents parallels with the critical engagements of the protest movement I was researching. Critiques from feminist (Ortner 1974) and postcolonial studies (Asad 1986; Bhaba 1994; Said 1978; Spivak 1988) were among the first to point towards the ways that situated positionalities and unequal power relations shaped academic knowledge. The Writing Culture debates which ensued (Clifford and Marcus 1986) questioned how anthropology had construed its ability to speak for others, and the reasons for which it believed it had the authority to do so. This extension of poststructuralist critiques to anthropology raised important concerns about the ethical and epistemological basis of the discipline, and cast doubt on the viability of producing knowledge conceived as a 'representation' of 'reality', or as a 'subjective' account of an 'objective' world. But this critical interrogation of how knowledge had been produced was extended to examine how knowledge had been conceived, and ethnographic encounters with the ideas of others showed that knowledge itself could be conceptualized in different ways (Holbraad and Pedersen 2017).

Bruno Latour's $(1993,2004)$ research into scientific laboratories (Latour and Woolgar [1979] 1986) has demonstrated that epistemic models of scientific truth are grounded in a conceptual 'bifurcation' (Latour 1993) between subject/object, nature/culture, representation/reality. While the 'great divide' between these concepts forms the basis of scientific claims to objectivity, Latour (Latour and Woolgar [1979] 1986; Latour 1993) shows that the processes through which scientific knowledge is produced in laboratory settings complicate these distinctions, and reveal the hybrid agencies at work. The role of technical objects in the production of scientific measurements, and the influence of funding organizations in the acceptance of some results at the expense of others, leads him to point to the heterogeneous assemblages of people and things, technologies and politics that participate in the production of scientific facts (Latour 2004: 227). Latour's (1993) analysis points to the impossibility of sustaining conceptual distinctions between society/technology, subjects/objects, representation/reality, or nature/culture, and calls for new ways 
of defining knowledge beyond the conceptual 'bifurcation' of Modern thought. Ethnographic encounters with other contexts have further complicated this model of knowledge, and the relativization of core analytical concepts such as culture (Wagner 1981), nature (Viveiros de Castro 1998, 2002), knowledge (Strathern 1988, 1991) and truth (Holbraad 2012) has challenged the universal status of anthropology's analytical toolkit. If the anthropological concepts through which we have sought to describe, interpret or analyse our ethnographic encounters with others are shown to lose their claims to universality, and are instead recast as relative, then what is the status of the knowledge they are able to produce? Eduardo Viveiros de Castro $(1998,2002,2014)$ argues that anthropological concepts are epistemically equivalent to the concepts of the people they study, and that anthropological knowledge is just one instance of indigenous knowledge (Viveiros de Castro 2002, 2014). The assertion that both 'anthropologist' and 'native' have equal claims to truth (Viveiros de Castro 2002) rejects the hierarchical position of anthropological discourse, and repositions our interlocutors as equal theorists, other 'anthropologists' whose analytic concepts offer new tools through which the anthropological project and its conceptual apparatus can be redefined. Martin Holbraad (2012) adopts this recursive approach in his ethnography of Cuban divination, where he draws on local concepts of 'truth' to develop an anthropological theory of truth that is ethnographically informed. The anthropological project proposed here seeks to remain open to the conceptual challenges presented by our ethnographic encounters with others, which may call for the extension of meanings (Holbraad 2012), the creation of concepts (Viveiros de Castro 2014) and a 'reverse anthropology' (Wagner 1981), which can challenge conventional understandings of what anthropology may be, or what it may do (Holbraad and Pedersen 2017).

\section{Experiments in comparative relativism}

The refusal of epistemic hierarchy defends a radical equality between truths, positioned as horizontal. Taking this relativist postulate as his starting point, the French philosopher Patrice Maniglier (2009) proposes a model of knowledge that is cumulative, evaluative and falsifiable. If we start with the proposition that 'I accept as true anything which could be conceived otherwise', then every truth claim is accompanied by its 'variants', ways in which it can be thought differently. Our task then becomes the familiar exercise of anthropological comparison: truth claims and their variants are placed in relation to each other and a third position is adopted, from which a comparative frame can be developed that can conceptualize them relationally. Through the comparative method, we can build a body of knowledge which is capable of producing new truth claims, as well as assessing them according to a falsifiability criterion. The question then becomes whether we are able to compare comparative frames themselves - the comparison of anthropologies (Viveiros de Castro 2014), rather than individual truth claims - such that the comparative frame itself may be conceived otherwise too. Of course, the comparative 
method itself must also be subject to ethnographic variance and critical scrutiny, if we are to build an anthropology that is robust:

The call to problematise the conditions of possibility of anthropological knowledge is subject to an apparently debilitating infinite regress. If these conditions of possibility are themselves to become part of the object of knowledge, then what are the conditions of possibility of that? (Holbraad and Pedersen 2009: 389)

While this recursive approach can have dizzying effects, its infinite regress is nonetheless reassuring, as it demonstrates a model of knowledge that can continually redefine itself and question its own conditions of possibility.

\section{Cutting the field}

The theoretical trajectory I have traced through anthropological knowledge (and its variants) has not solved the epistemological crisis that had affected me as I began my research, but it has suggested a course of action: rather than allow my ethnographic dilemma to halt my research, it could become my main research question. Can we produce knowledge horizontally, in a way that does not produce hierarchical 'representations' of others? How can we know at all, and can we do so ethically? This was the point of departure for my twelve-month period of field research among the midiativista movement of Rio de Janeiro in 2014. I chose to 'cut the network' (Strathern 1995) around midiativistas as their commitment to producing knowledge of the movement from within, and their rejection of the knowledge produced by others, suggested it would be a promising site from which to explore how knowledge may be conceived otherwise. By examining the practices, processes and concepts through which midiativistas produced knowledge themselves, I recursively deploy their concepts and methods of knowledge production as the modus operandi of my own project. Here, my primary goal is not to provide a detailed ethnographic account of their knowledge practices - though I do this by default - but instead I aim to develop an analytical framework through which I can confidently produce anthropological knowledge, in a way that can stand up to the ethical and epistemological demands of my interlocutors. In doing so, I hope to contribute towards an anthropological theory of truth that is ethnographically informed.

\section{Producing knowledge with midiativistas: running towards}

I had fallen behind, and was towards the back of the protest when I heard the first stun grenade. Smoke filled the air and people ran in all directions. At first, I found myself instinctively running with them, away from the noise and smoke. Suddenly I stopped, and it occurred to me that if I wanted to research midiativismo, I should be running towards the confrontation, not away from it. The decision to run towards the front lines of protest spaces was a defining characteristic of midiativista action. My collaborators distinguished themselves from a 'citizen journalist', which they 


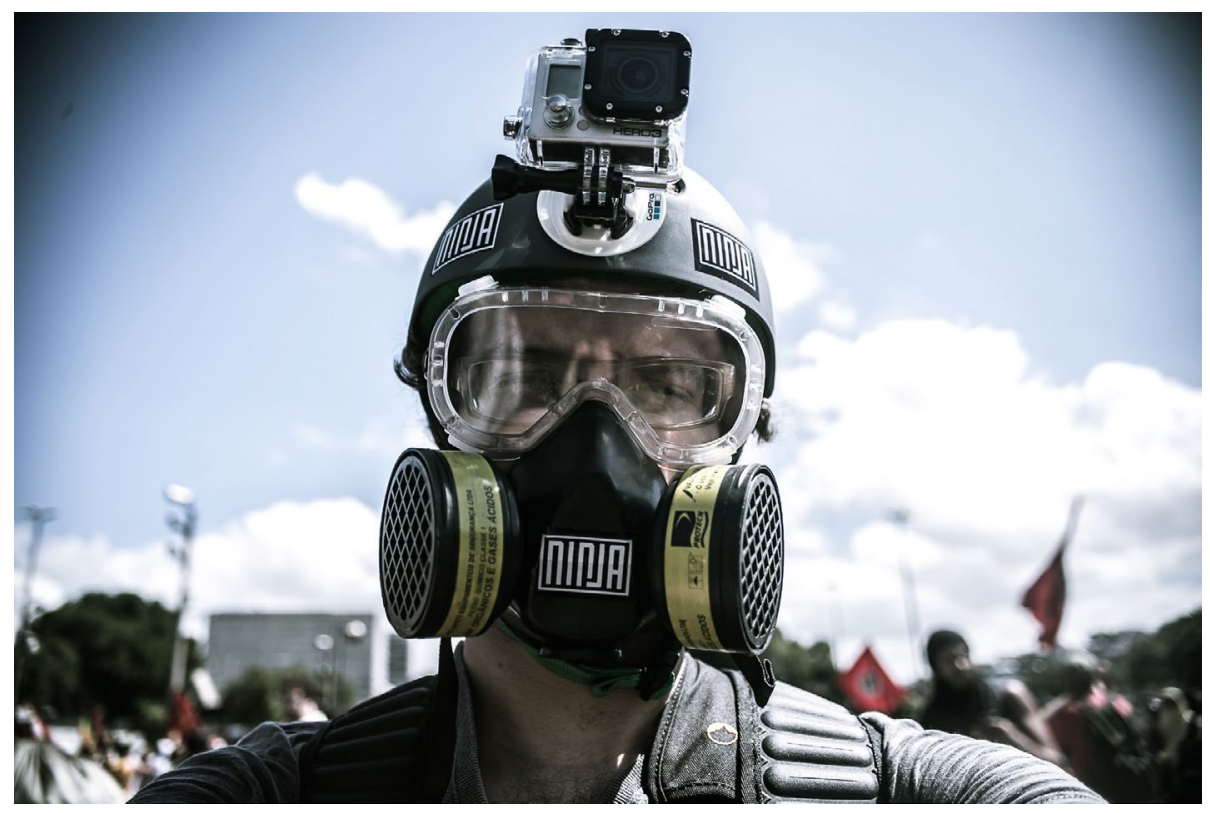

Figure 2: Midiativistas' protective equipment enables them to withstand hostile environments. Photograph by Thiago Dezan.

described as a witness-by-chance, who happens to find themselves in a position to witness a situation, which they might document on their phones and then share with digital networks. In contrast, the midiativista is a witness-by-choice, who makes an intentional decision to put themselves in situations where they think a witness - especially one equipped with a camera - may be needed. The decision to run towards, rather than away from, was also a defining moment in my research. It was a decision to be a midiativista, and occupy the protest space in a way a midiativista does, and consequently it was a decision to be an ethnographer, committed to 'being there' and 'doing with' with my collaborators, and placing myself in the spatial and relational position required for knowledge.

The possibility of running towards the confrontation, rather than away from it, depended on essential protective technologies - goggles to protect the eyes from rubber bullets, pepper-spray and teargas; a helmet to protect the skull from police batons and shrapnel; gas masks to permit the lungs to breathe in these conflict zones. These protective technologies transformed midiativistas' bodies into cyborg figures (Haraway 1985), people-with-gas-masks (Warnier 2009), heterogeneous assemblages of people and things (Latour 1993) which were able to withstand hostile environments and 'be there' on the front lines. Once there, their recording apparatus was an essential component of what they saw themselves as there to do: to witness events and produce audiovisual testimony (Schankweiler et al. 2019) of their encounters. Their cameras, with lenses, spare batteries and memory cards, 


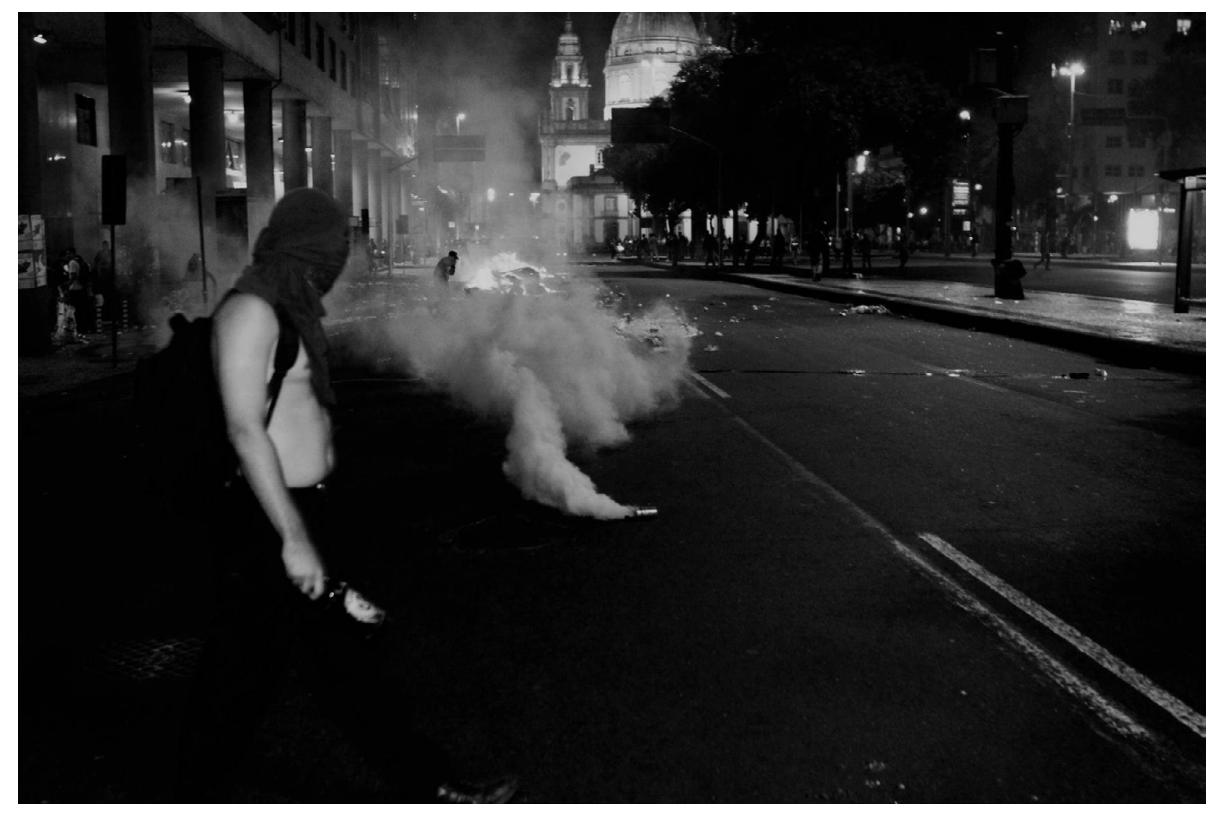

Figure 3: Midiativistas transformed the dark streets they witnessed by ensuring they were seen by others. Photograph by Daniel Cruz.

formed a network of devices that enabled midiativistas to record their encounters and extend witnessing beyond the immediate event, into digital networks where audiences become second-hand witnesses (Ellis 2000), 'media witnesses' (Frosh and Pinchevski 2009; McLagan 2006) or 'connected witnesses' (Mortensen 2015). Both the safety equipment and recording devices through which midiativistas were able to extend the public eye to these streets articulated a capacity to 'see' that was materially distributed through a socio-technical network of people and things (Latour 1993), made possible by the physical presence of that particular midiativista, pointing her camera in that direction, showing us the situated and partial world presented to her vision, and consequently to ours.

Midiativistas 'were there' on the front lines of protests, in a position from which they could bear witness to the events that took place, and which granted them the authority through which they felt qualified to speak. Midiativistas differentiated themselves from mainstream news outlets precisely on this point; while they were there on the streets, which granted them the physical position and relational matrix from which to encounter the scene and bear witness, Brazilian corporate news giant Rede Globo was criticized for flying in a helicopter above, recording the view 'from everywhere' which impeded them from recording what was 'really happening' below, or establishing relations with the people present. For midiativistas, the authority of a truth claim comes from the person who 'was there' - from the 
direct witness and their immediate affective encounter with the world. Midiativista truth is a view from someone, and derives its credibility through the partial and situated location in which that person stood. In this sense, Globo's attempt at a 'view from everywhere' resulted in a 'view from nowhere', or more specifically, a 'view from no-one', and their claims to truth are rejected because they are not situated, not grounded in a particular person's encounter with the streets below. What is being rejected is precisely the distance that classic models of journalistic truth - and indeed positivist scientific truth - strive for. Here, objective truth is rejected as both impossible and undesirable: the fact that Globo 'were not there' on the streets, but rather in a helicopter above, was seen to deny them an insider position from which they could derive authority to speak. ${ }^{2}$ The social relations and spatial position through which knowledge is produced shapes the knowledge that results, and claims to authority are grounded here in the situated encounter through which such knowledge-making took place. Midiativistas' proximity to events enabled them to witness details which Globo's helicopter could not, and the insider reports they produced permitted them to contest the mainstream media's narratives of events. In some cases, midiativista videos served to refute accusations of protestor wrongdoing, and mainstream media networks were forced to retract their reports.

You would see Globo changing their story, changing their tone, and they were stuck because we had a video proving exactly the opposite of what they had reported ... [then] society has the opportunity, other channels, other opinions to listen to, not only this monopoly of information, everything on one channel ... which is a single truth. (Interview with Carol, a midiativista working independently)

This multiplicity of partial and situated accounts contests Globo's claims to impartiality, challenging its legitimacy to define 'truth' in the singular, and its status as a univocal truth provider, as well as the mono-realist model of truth upon which it is grounded.

Here, objective or impartial truth is rejected as an a priori impossibility: the midiativistas' position in space and in a relational web are the conditions of possibility of the truth they are able to articulate. A concept of truth as detached from an observer makes no sense for midiativistas - a truth is always someone's truth, produced through their immediate encounter with the world. The immediate sensory encounter with the world produces an 'affect' (Deleuze 1994; Deleuze and Guattari 1987; Massumi 1987, Massumi 2002), an intensity of experience described as the capacity to act and be acted upon (Massumi 2002), which allows for a movement between one state of intensity and another. The comparison between states - between where one was and where one is now - is, for Deleuze and Guattari (1987), the movement required for knowledge. The affective encounters through which midiativista witnessing takes place (Richardson and Schankweiler 2019) are communicated and extended to others, and the medium in which they are communicated shapes the ways in which others are able to encounter them in 
turn. The visceral and non-discursive way in which midiativista videos extend their encounters does not rely on linguistic representations, but rather on affective intensities, and the transformations made possible by the process of becoming 'affected'. If 'objective truth' has been rejected as disembodied, unattainable, truths-from-nowhere, then the appeal to immersed, embodied, truths-from-here can be understood as the basis for an alternative theory of truth articulated by midiativistas.

\section{The anthropology of witnessing}

The specificity with which midiativistas understood their acts of witnessing presents a clear and well-defined local concept of the 'witness', which they build on to develop a nuanced theory of truth conceived as partial, situated and multiple. But the ethnographic specificity of this concept of witnessing is just one instance of how witnessing has been or can be understood. My anthropological account of midiativista witnessing, like the truths that midiativistas produce, must also be understood as the situated and partial testimony of a particular anthropologist's encounter.

The existing anthropological literature on witnessing (Chua 2015; Fassin 2008; Givoni 2011, 2013; Grindal 1983; Marcus 2005; Reed-Danahay 2017; ScheperHughes 1995) presents diverse concepts of what witnessing is and what it entails, and suggests different ways to enact it. Within this diversity, however, the distinction between participation (Scheper-Hughes 1995) and observation (Marcus $2005,2010)$ recurs in different forms, though while authors invariably concede that boundaries are blurred, few have abandoned the distinction altogether (with some exceptions, notably Grindal [1983: 76] and Reed-Danahay [2017: 62]). The Latin etymology of the term distinguished between testis (fact), superstes (experience) and martyr (action) (Givoni 2013). The separation of 'fact' from 'experience' reifies a clear-cut distinction between observation and participation, subject and object, representation and reality, and the definition of the term in this way has limited applicability in ethnographic contexts where these concepts are problematized. The form of witnessing that midiativistas in my field site articulated challenges this division between fact and experience, or indeed between experience and action, and calls for an anthropological concept of witnessing capable of leaving those distinctions behind.

This division between participation and observation has shaped the ways in which the term has been applied to anthropology, and how the anthropologist has been understood as witness. This has been the subject of particular concern in contexts of violence and social conflict, where the ethical role of the anthropologist as either 'detached observer' (Marcus 2005, 2010) or engaged participant and advocate (Scheper-Hughes 1995) has been hotly debated. For George Marcus (2005), the ethical challenges posed by conflict zones leave few options for anthropological participation. He argues for the position of the witness, conceived as a 'detached' and 'disinterested' observer, which he sees as a means of enabling anthropologists to avoid taking sides, preserving the professional distance he considers important in 


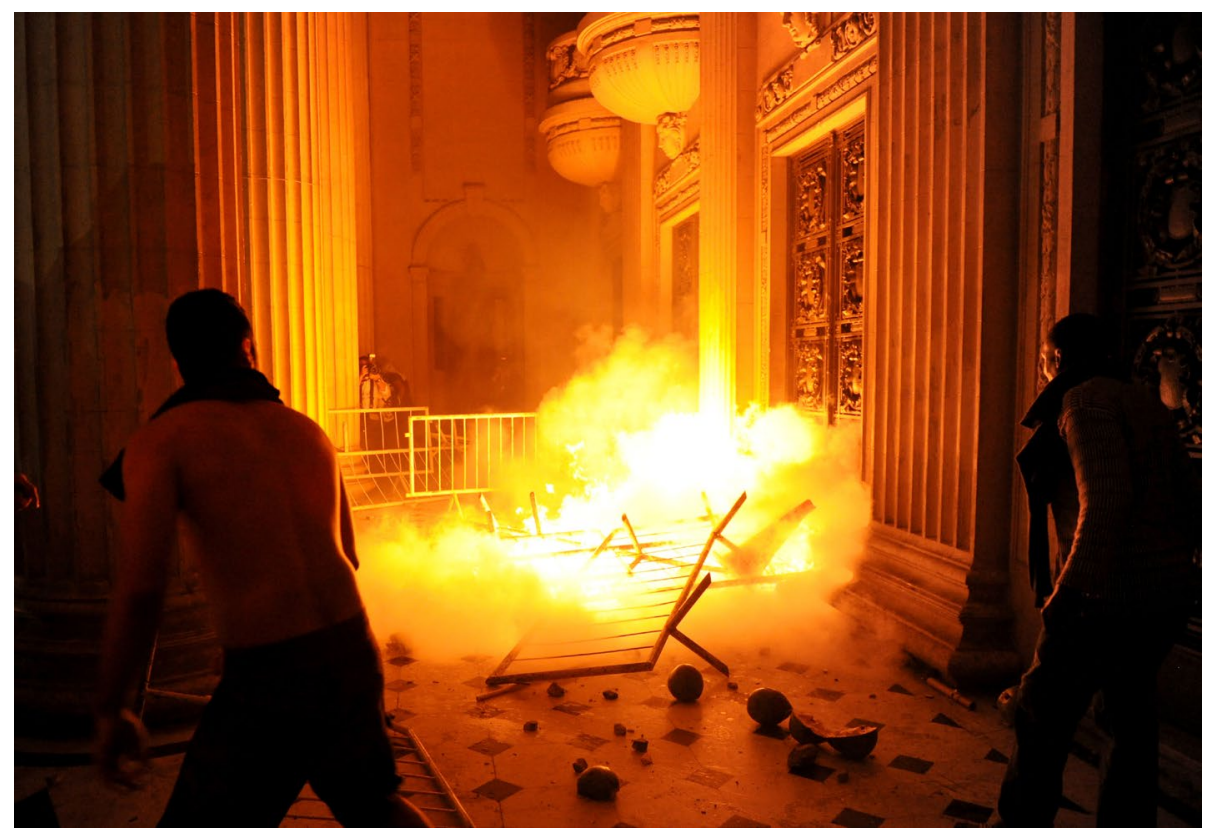

Figure 4: This image of protestors outside Rio de Janeiro's City Hall shows the relation of trust between midiativista and protestors. Photograph by Daniel Cruz.

the production of anthropological knowledge. Midiativistas, however, always take sides. Indeed, for midiativistas, taking a side - both in terms of physical position and social relation - is what makes bearing witness possible in the first place, and is a condition of possibility of the production of knowledge. This can be illustrated both in terms of geographical position in space - which is both the condition and the limit of occupying a perspective - and in terms of the relational matrices which provide access to some spaces at the cost of others. Many midiativista collectives would spread out across the protest, and some would stay close to the police lines and record the police as they fired non-lethal weapons, while others would stay close to protestors, and record their retaliation with improvised projectiles and Molotov cocktails. The perspectives offered by each side were mutually exclusive one person could only film from the geographical side they were on, and it was impossible to film both at the same time. On the other hand, the intimate images that midiativistas recorded of protestor resistance were only possible because of the relations of trust that they had established with the 'black blocks'3 (Dupuis-Deri 2014) who led the retaliation. These intimate witness positions were only granted to midiativistas whom protestors trusted as being 'on their side', and therefore trusted to only publish images that would not reveal their identities. To remain 'detached' or 'on the fence' here would have been understood by participants as a failure to take their side, and access would have been denied. 
Nancy Scheper-Hughes (1995) also describes the ways in which the field access she was granted by her interlocutors was dependent on the role she chose to adopt within the community. She recounts a situation where, upon changing the form of her participation from active community member to passive outside observer, she was questioned by her interlocutors and told that the access she had been given to her field site would be withdrawn. She points out the ways in which her decisions to develop social bonds with some collaborators inevitably excluded interactions with others, and suggests that there is 'little value in false neutrality' (1995: 419). In contrast to Marcus's (2005) proposal for a detached form of anthropological witnessing, Scheper-Hughes (1995) has repeatedly called for anthropologists to take action in field sites marked by social injustice, and argues for an anthropology that is both politically and morally engaged (1995: 415). However, while Scheper-Hughes (1995) raises important questions about the politics of anthropological positioning in contexts of violence, the grounds upon which she defends her calls for intervention are both epistemologically and ethically problematic. While midiativistas argue that taking sides is a necessary condition of the spatial and relational requirements for knowledge - and therefore an epistemological act - Scheper-Hughes (1995: 419) proposes that anthropologists have a moral obligation to 'take sides' and speak out in the face of injustice. But the ethical codes and concepts of morality through which she evaluates and identifies injustices are unapologetically her own, and the universal applicability of her ethical ideals is never in question. 'To speak of the "primacy of the ethical" is to suggest certain transcendent, transparent, and essential, if not "precultural" first principles' (1995: 419). Here, Scheper-Hughes' (1995) recourse to a notion of ethics that is predefined and understood as essential, transcendent and impervious to reconceptualization is starkly at odds with the ethical demands of midiativistas and the radical horizontality to which they are committed, and is both epistemologically and ethically problematic. Instead, following the partial, relative and multivocal model of knowledge and truth articulated by midiativistas, I propose that anthropological concepts of ethics, and the ethical practice they entail, should be empirically and ethnographically informed. This is not to relativize ethics beyond utility, or to deny the ethical frameworks of the anthropologist. Rather, it is to commit to a concept of ethics that is produced relationally, where variants are understood comparatively in relation to each other. It is to admit that neither anthropologist nor the members of their host communities have a privileged position from which to define the 'ethical', but rather both can offer particular, situated instances of an ethical code which must be equally acknowledged. The ontological superiority implicit in Scheper-Hughes' (1995) assertion of ethical essentialism is a stark denial of the capacity or authority of others to define the world and how they should live in it. 


\section{Witnessing thought otherwise}

This article has presented an ethnographically specific concept of witnessing that emerged among midiativistas in their efforts to produce knowledge and intervene in protest spaces in Rio de Janeiro. The particular characteristics of this kind of witnessing - as a form of participative and intentional 'direct action' (Graeber 2009) - place it in contrast to the ways in which witnessing has been understood and practised in other ethnographic and historical contexts. In this way, midiativista witnessing presents a variant (Maniglier 2009) of witnessing which enables the concept to be rethought and redefined in relation to the different ways in which it has been conceived. The goal here must be to articulate an analytical position from which the multiple ethnographic variants of witnessing can be examined comparatively. This is not to seek to homogenize the concept - quite the opposite: it is to articulate a concept that can redefine itself in relation to the multiplicity of ways in which it can be thought and practised otherwise.

In this endeavour, I have already commented on the ways in which the conceptual division of witnessing into fact, experience and action that is implicit in the term's Latin root cannot be sustained in light of my ethnography. While part of the literature expresses a desire to move beyond the tripartite division (Peters 2009), the division between detached observation and engaged participation remains, seemingly unable to overcome the Modern 'bifurcation' (Latour 1993) as a grounding conceptual framework. To develop a concept of witnessing that is capable of redefining itself in relation to the multiplicity of variant forms that have already been described, as well as future variants that are inevitably to come, we might begin to question the viability of 'witnessing' as a concept that has shown resistance to abandoning the divisions between subject/object, representation/reality on which it was founded. Can 'witnessing' ever overcome these conceptual divisions that have historically defined the term, in order to become a useful tool for the comparative task at hand? Other terms have been proposed instead, such as 'co-presence' (Beaulieu 2010; Chua 2015), which is intended to move beyond 'the unidirectional and oculocentric connotations of witnessing' (Beaulieu 2010: 457) and acknowledge the 'relational and often ephemeral condition that arises when various entities come together and act on each other' (Chua 2015: 642). The Deleuzian (1994) concept of 'affective encounter' also seeks to evoke a shift in thinking away from the boundaries of the subject/object division, while the being-there and doing-with terminology that my ethnography proposes points to the importance of action and participation, evoking all three components of testis, superstes and martyr in one. If the question of how we participate in our fields is also the question of how we know our fields, then upon which grounds do we maintain the distinction between knowledge and action, or epistemology and ethics? While we have considered the multiple variants of witnessing, could witnessing be understood as a variant of knowledge, cast as political and ethical action? 


\section{Conclusion}

Midiativistas produced knowledge as a form of direct action. They intentionally positioned themselves on the front lines of protests in order to act as witnesses, and produced audiovisual testimony from where they stood. Their capacities for action were shaped by the socio-technical assemblages they deployed: gas masks transformed their bodies' capacity to breathe in hostile zones, while their cameras extended these encounters beyond the event, making them visible and open to be witnessed by others elsewhere. Midiativistas' acts of observation directly intervened in the protest spaces they witnessed, transforming the dark streets where police violence went unnoticed into highly contested sites of public scrutiny. Midiativistas articulated a model of truth as situated and partial, made possible through our affective encounters with the world, and challenged claims to detached observation and objective truth.

The ethnographically informed concept of witnessing that I outline presents a 'variant' to existing definitions of the witness, further complicating distinctions which are already blurred. The line that separates observation from participation is untenable for my collaborators - they are seen as mutually dependent - meaning that observation is always already an act of participation. The question then becomes not if one participates, but how one chooses to participate, and how this shapes the knowledge that can be accessed. Both the ethical codes that inform our action and the epistemological concepts that ground our knowledge in different ethnographic contexts must be co-defined relationally, from a position that can account for both the anthropologist and her interlocutors. The theories and methods of knowledge must be established collaboratively, horizontally, and where possible informed ethnographically, if we are to produce knowledge that is ethically and epistemologically sound.

This special issue makes an important contribution towards an anthropological theorization of witnessing. Its focus on the technologies through which truths are produced and through which the world is transformed has raised urgent questions not only about witnessing, but about anthropological technologies, truths and transformations. How does the technological apparatus deployed by anthropology shape the kinds of encounters made possible through ethnographic witnessing? While cameras and sound recorders often form part of anthropological toolkits, the recordings they make are still deemed supplementary to anthropological knowledge proper - text. My own affective encounters as witness on the front lines of protest spaces have been extended here through language, descriptions, concepts and visual imagery. Even the video I co-produced - an important ethnographic artefact - was textually translated in order to be included here. Perhaps the technologies through which anthropological truths are produced, and the worlds they then transform, should be examined more carefully, to inform a more considered assemblage of technical devices than the traditional notebook and pencil. We might find that our field sites can be extended affectively and encountered by our colleagues in conceptually productive ways. 
I began this article with a transcript of a video, which was collaboratively produced by six midiativistas, of which I was one. The situated position of each midiativista made possible the partial yet authoritative audiovisual testimony of their unique encounter with the world. The six partial reports come together to allow a vision of the world from six different positions, where the comparative method enables us to view all six as variants of the other. This special issue is also composed of six situated and partial ethnographies, of which I am also one, where complex engagements with diverse research sites each present unique ethnographically informed accounts of witnessing. An exercise in comparison also allows us to bring the different positions here in relation to each other, articulating a comparative frame through which relative truths can be drawn together into a cumulative world of vision.

Raffaella Fryer-Moreira is a PhD candidate at the Department of Anthropology, University College London. Raffaella is the co-founder and director of the UCL Multimedia Anthropology Lab, and is currently completing doctoral research among Guarani and Kaiowá indigenous communities in Brazil.

Email: raffaella.fryer-moreira.09@ucl.ac.uk

\section{Notes}

1. The names of all collaborators have been changed to protect their identities.

2. Globo's reports were also rejected by midiativistas for being 'manipulated', choosing particular terminologies and presenting information selectively in order to further the specific political agendas of their primary funders - the state. See Fryer-Moreira 2016.

3. Black blocks were activists who chose a confrontational strategy in protests. This movement has been documented in detail by other scholars (Dupuis-Deri 2014).

\section{References}

Asad, T. 1986. 'The Concept of Cultural Translation in British Social Anthropology'. In J. Clifford and G. E. Marcus (eds), Writing Culture: The Poetics and Politics of Ethnography. Berkeley: University of California Press, 141-164.

Beaulieu, A. 2010. 'Research Note: From Co-Location to Co-Presence: Shifts in the Use of Ethnography for the Study of Knowledge'. Social Studies of Science 40 (3): 453-470. https://doi.org/10.1177/0306312709359219.

Bhabha, H. 1994. The Location of Culture. London: Psychology Press.

Borneman, J. and A. Hammoudi (eds). 2009. Being There: The Fieldwork Encounter and the Making of Truth. Berkeley: University of California Press.

Chua, L. 2015. 'Troubled Landscapes, Troubling Anthropology: Co-Presence, Necessity and the Making of Ethnographic Knowledge'. Journal of the Royal Anthropological Institute 21 (3): 641-659. https://doi.org/10.1111/1467-9655.12254.

Clifford, J. and G. E. Marcus (eds). 1986. Writing Culture: The Poetics and Politics of Ethnography. Berkeley: University of California Press. 
Deleuze, G. 1994. Difference and Repetition, trans. P. Patton. New York: Columbia University Press.

Deleuze, G. and F. Guattari. 1987. A Thousand Plateaus: Capitalism and Schizophrenia, trans. B. Massumi. London: Continuum.

Dupuis-Deri, F. 2014. Who's Afraid of the Black Blocs? Anarchy in Action around the World. Oakland, CA: PM Press.

Ellis, J. 2000. Seeing Things: Television in the Age of Uncertainty. London: I. B. Tauris.

Fassin, D. 2008. 'The Humanitarian Politics of Testimony: Subjectification through Trauma in the Israeli-Palestinian Conflict'. Cultural Anthropology 23 (3): 531-558. https://doi.org/10.1111/j.1548-1360.2008.00017.x.

Fassin, D. 2011. 'A Contribution to the Critique of Moral Reason'. Anthropological Theory 11 (4): 481-491. https://doi.org/10.1177/1463499611429901.

Frosh, P. and A. Pinchevski. 2009. 'Introduction: Why Media Witnessing? Why Now?' In P. Frosh and A. Pinchevski (eds), Media Witnessing: Testimony in the Age of Mass Communication. Hampshire: Palgrave Macmillan, 1-19.

Fryer-Moreira, R. 2016. “'A gente tava ali”: Repensando a Verdade com Midiativistas no Rio de Janeiro' ['We were there': rethinking truth with midiativistas in Rio de Janeiro]. Masters diss., Federal University of Rio de Janeiro.

Givoni, M. 2011. 'Witnessing/Testimony'. Mafte'akh: Lexical Review of Political Thought (2): 147-169. http://mafteakh.tau.ac.il/en/wp-content/uploads/2011/01/Witnessing Testimony-.pdf.

Givoni, M. 2013. 'The Ethics of Witnessing and the Politics of the Governed'. Theory, Culture \& Society 31 (1): 123-142. https://doi.org/10.1177/0263276413488633.

Graeber, D. 2009. Direct Action: An Ethnography. Edinburgh: AK Press.

Grindal, B. T. 1983. 'Into the Heart of Sisala Experience: Witnessing Death Divination'. Journal of Anthropological Research 39 (1): 60-80. https://doi.org/10.1086/ jar.39.1.3629816.

Haraway, D. 1985. 'A Cyborg Manifesto: Science, Technology, and Socialist-Feminism in the Late Twentieth Century'. Socialist Review (80): 65-108. https://doi.org/10.1007/ 97814020380374.

Holbraad, M. 2012. Truth in Motion: The Recursive Anthropology of Cuban Divination. Chicago: University of Chicago Press.

Holbraad, M. and M. A. Pedersen. 2009. 'Planet M: The Intense Abstraction of Marilyn Strathern'. Anthropological Theory 9 (4): 371-394. https://doi.org/10.1177/ 1463499609360117.

Holbraad, M. and M. A. Pedersen. 2017. The Ontological Turn: An Anthropological Exposition. Cambridge: Cambridge University Press.

Latour, B. 1993. We Have Never Been Modern, trans. C. Porter. Cambridge, MA: Harvard University Press.

Latour, B. 2004. 'Why Has Critique Run Out of Steam? From Matters of Fact to Matters of Concern'. Critical Inquiry 30 (2): 225-248. https://doi.org/10.1086/421123.

Latour, B. and S. Woolgar. (1979) 1986. Laboratory Life: The Construction of Scientific Facts. Princeton, NJ: Princeton University Press.

Lobato, C. 2016. 'Devires democráticos e alter-políticas: ensaio etnográfico sobre assembleias horizontais do Rio de Janeiro' [Democratic becomings and alter-politics: ethnographic essay on the horizontal assemblies of Rio de Janeiro]. Masters diss., Federal University of Rio de Janeiro. 
Maniglier, P. 2009. 'The Others' Truths: The Logic of Comparative Knowledge'. Departmental Seminar of the Department of Philosophy of the University of Essex.

Marcus, G. E. 2005. 'The Anthropologist as Witness in Contemporary Regimes of Intervention'. Cultural Politics 1 (1): 31-49. https://doi.org/10.2752/174321905778054890.

Marcus, G. E. 2010. 'Experts, Reporters, Witnesses: The Making of Anthropologists in States of Emergency'. In D. Fassin and M. Pandolfi (eds), Contemporary States of Emergency: The Politics of Military and Humanitarian Intervention. New York: Zone Books.

Marcus, G. E. and M. F. Fischer. 1986. Anthropology as Cultural Critique: An Experimental Moment in the Human Sciences. Chicago: University of Chicago Press.

Massumi, B. 1987. 'Introduction'. In G. Deleuze and F. Guattari, A Thousand Plateaus: Capitalism and Schizophrenia. London: Continuum.

Massumi, B. (ed.). 2002. A Shock to Thought: Expression after Deleuze and Guattari. London: Routledge.

McLagan, M. 2006. 'Introduction: Making Human Rights Claims Public'. American Anthropologist 108 (1): 191-195. https://doi.org/10.1525/aa.2006.108.1.191.

Mortensen, M. 2015. 'Connective Witnessing: Reconfiguring the Relationship between the Individual and the Collective'. Information, Communication \& Society 18 (11): 1-14. https://doi.org/10.1080/1369118X.2015.1061574.

Ortner, S. 1974. 'Is Female to Male as Nature is to Culture?' In M. Z. Rosaldo and L. Lamphere (eds), Women, Culture and Society. Stanford, CA: Stanford University Press, 67-87.

Peters, J. D. 2009. 'Witnessing'. In P. Frosh and A. Pinchevski (eds), Media Witnessing: Testimony in the Age of Mass Communication. Basingstoke: Palgrave Macmillan, 23-41.

Pomar, M. 2013. 'Introdução: Não Foi um Raio em Céu Azul' [It wasn't a lightning bolt in a blue sky]. In Vinte Centavos: a Luta Contra o Aumento [Twenty cents: the struggle against the fare rise]. São Paulo: Veneta.

Reed-Danahay, D. 2017. 'Participating, Observing, Witnessing'. In S. Coleman, S. B. Hyatt and A. Kingsolver (eds), The Routledge Companion to Cultural Anthropology. New York: Routledge, 57-71.

Richardson, M. and K. Schankweiler. 2019. 'Affective Witnessing'. In J. Salaby and C. von Scheve (eds), Affective Societies: Key Concepts. Abingdon: Routledge, 166-177.

Said, E. W. 1978. Orientalism. New York: Pantheon.

Schankweiler, K., V. Straub and T. Wendl (eds). 2019. Image Testimonies: Witnessing in Times of Social Media. London: Routledge.

Scheper-Hughes, N. 1992. Death without Weeping: The Violence of Everyday Life in Brazil. Berkeley: University of California Press.

Scheper-Hughes, N. 1995. 'The Primacy of the Ethical: Propositions for a Militant Anthropology'. Current Anthropology 36 (3): 408-420. https://doi.org/10.1086/204378.

Spivak, G. C. 1988. 'Can the Subaltern Speak?' In C. Nelson and L. Grossberg (eds), Marxism and the Interpretation of Culture. London: Macmillan.

Strathern, M. 1988. The Gender of the Gift: Problems with Women and Problems with Society in Melanesia. Berkeley: University of California Press.

Strathern, M. 1991. Partial Connections. Savage, MD: Rowman and Littlefield.

Strathern, M. 1995. 'Cutting the Network'. Journal of the Royal Anthropological Institute 2 (3): 517-535. https://doi.org/10.2307/3034901. 
Viveiros de Castro, E. B. 1998. 'Cosmological Deixis and Amerindian Perspectivism'. Journal of the Royal Anthropological Institute 4 (3): 469-488. https://doi.org/10.2307/ 3034157.

Viveiros de Castro, E. B. 2002. 'O Nativo Relativo' [The Relative Native]. Mana 8 (1): 113-148. https://doi.org/10.1590/S0104- 93132002000100005.

Viveiros de Castro, E. B. 2014. Cannibal Metaphysics: For a Post-Structural Anthropology, trans. P. Skafish. Minneapolis: Univocal Publishing.

Wagner, R. G. 1981. The Invention of Culture. Chicago: University of Chicago Press.

Warnier, J. P. 2009. 'Technology as Efficacious Action on Objects ... and Subjects'. Journal of Material Culture 14 (4): 459-470. https://doi.org/10.1177/1359183509345944. 